Marcin Fatalski

Institute of American Studies and Polish Diaspora Jagiellonian University, Krakow, Poland

\title{
The United States and the Fall of the Trujillo Regime
}

\begin{abstract}
Rafael Trujillo, who governed the Dominican Republic in the years 1930-1961, was one of the most recognizable Latin American dictators. Trujillo created one of the most repressive regimes in Central America, even when compared with other dictatorships of this cruelly governed region. Till the late 1950s, his position in the eyes of U.S. policymakers was stable. He maintained order in the country and upheld an anti-Communist policy, both an internal and foreign one. In the late 1950s, the Trujillo regime became the subject of growing criticism in the United States and other American republics. The Eisenhower and Kennedy administrations were concerned that a continuation of the Trujillo regime would provoke a Castro-like revolution in the Dominican Republic. Kennedy also criticized Trujillo for his violation of human rights, which was contrary to the new program of U.S. policy toward Latin America. Kennedy promoted democracy and reform to avoid the threat of a Communist revolution. The U.S.A. supported the conspiracy against Trujillo in order to overthrow the dictator and establish a "moderate pro-American government." After the assassination of the dictator, pressure from the U.S. frustrated Trujillo's son's attempts to maintain the regime, and protected the transition of the Dominican Republic to a democratic system.
\end{abstract}

$\mathrm{R}$ afael Leonidas Trujillo Molina, the dictator of the Dominican Republic, had been a close ally of the United States for many years. The strong ties between these two countries existed before Trujillo took power, since this small Caribbean country is located in the close vicinity of the United States. Central America and the Caribbean is the region where the U.S.A. began to create its sphere of influence in the Western Hemisphere. The U.S. administrations have been able to influence the countries in that region politically and make them dependent economically earlier than in other parts of Latin America (Łepkowski, 1979: 283-289, 427; Gilderhus 8-10; Gruszczak 81-86; Kłosowicz 274; Smith 24-26). The Dominican dictator was fully aware that the United States could be the best supporter of his regime if he were able to secure the unconditional support of his country for the American giant (Taffet 125). The U.S. administration supported the Trujillo regime for the same reason which played such 
a significant role in the general U.S. policy in the region: the dictatorship kept order and stability in the country, and the policy of the regime secured the U.S.'s political and economic interests there. The ability of a Central American government to maintain stability and a pro-U.S. position in economic and political relations defined the U.S.'s attitude toward such a government.

These factors played an even more significant role during the Cold War. The outbreak of global rivalry with the Soviet Union made the United States especially vulnerable for foreign influences in their own area of influence. However, in the early period of the Cold War the United States focused rather on the European arena of confrontation with Moscow (Kissinger 487-510). The situation in the Western Hemisphere was somewhat neglected. The Truman administration was preoccupied mainly by the events in Europe and, next, Eastern Asia. U.S. policymakers were convinced in that early phase of the Cold War that the Western Hemisphere was free from the Communist threat in comparison with the other parts of the world (Schoultz 332-333). ${ }^{1}$ But at the beginning of the 1950s, the perspective of Washington started to change. The U.S. administration began to consider Latin America as an arena of confrontation with what was called by American policymakers the "Sino-Soviet bloc." The extent of the real Soviet influence in Latin America during that period is a subject of debate. In fact, foreign influence is not a sufficient explanation for the postwar radicalization of societies in Latin America (Eakin 269). Radical movements had always existed in Latin America as a consequence of tremendous economic inequalities and social tensions. But after the Second World War, as in other parts of the world, the social protest movements gained a new tool to express their aims: Marxism. The fact that the Soviet Union became the second superpower made communism a point of reference for all left-wing radicals of the Third World (Eakin 269-270; Łepkowski 1983: 296-297).

This process also took place in Latin America. The postwar radicalization of Latin American societies was influenced by traditional populism and communist ideas. But the subversive activity was not organized or financed by the Soviet Union (or communist China). It was a natural continuation of the revolutionary movements which had always existed in Latin America (Eakin 317-318).

The Eisenhower administration was very worried about the situation in Latin American countries. The region was a subject of particular concern for the Secretary of State, John Foster Dulles. Dulles's worldview was concentrated around a global confrontation with communism. At the Senate hearing, as a candidate for the post of Secretary of State, Dulles described communism as the greatest threat for the world. Dulles said during the hearing, "We shall never have a secure peace and a happy world so long as Soviet communism dominates one third of all the peoples that there are and it is in the process of trying at least to extend its rule to many others (M.F.)" (Hearings 5-6). One of the regions which were considered by Dulles as an area of potential Soviet activity was Latin America. At the quoted hearing he compared the situation in Latin America at beginning of the 1950s to the situation in China in the

\footnotetext{
Bogotazo was the moment when the United States publicly blamed international Communism on inspiring the revolutionary movement in Latin America. But even then, politicians did not believe in the actual involvement of communists (and the Soviet Union) in the events which led to the outbreak of many years of violence in Colombia (Łepkowski 1983: 219).
} 
1930s. He was concerned about the extent of leftwing radicalism in Latin America in the historical perspective (Rabe 1988: 29).

This is why the Eisenhower administration rejected any kind of leftist attitude among Latin American political and social movements. The United States decidedly fought against all movements and leaders which could be attributed to left wing radicalism. In fact, even reformist programs were treated with suspicion. A deviation from pro-American foreign policy was treated in Washington as an expression of Soviet sympathies. A strong example of the U.S.'s attitude toward the Latin American revolution at that time remains Guatemala. The Eisenhower administration and John Foster Dulles personally were involved in the overthrow of Jacobo Arbenz Guzman's government. The United States accused the Guatemalan president of an alliance with the Soviet Union and was involved in the coup d'etat which ousted Guzman from office and opened a long period of repressive dictatorship in that country (Rabe 1988: 42-63).

The general assumptions described earlier in this article determined U.S policy toward the Dominican Republic throughout the early 1950s. Trujillo guaranteed the pro-U.S. position of his country in international politics, fought against communism, and maintained order in his country. His economic policy could hardly be described as market-oriented, since his family totally dominated the national economy. Anyway, the system was based on private property and Trujillo was able to build a relatively prosperous economy with the middle class as the core of the society.

Rafael Leonidas Trujillo Molina governed the Dominican Republic in an extremely brutal way, becoming a symbolic figure among Latin American dictators. He was, as American historian Stephen Rabe described him, "a product of the Dominican national guard" which was created by U.S. marines (1988: 153-154). Trujillo started his military career during the American occupation of the Dominican Republic. He quickly climbed through the ranks, ending up as chief commander of the National Guard (the Dominican armed forces). Trujillo gained power in 1930. He used the popular opposition toward President Vasquez's regime, which grew rapidly as a consequence of the economic crisis in 1929-1930. The president resigned under the pressure of a mass march supported by the military. As a consequence of the elections decided by the provisional head of state, Leonidas Trujillo became president of the republic (Łepkowski 1979: 288-289).

During his thirty-year rule, he gained the appalling fame of one of the cruellest Latin American dictators. The system created by Trujillo is sometimes called "Bonapartist." But, in fact, Trujillo created a totalitarian regime which can be compared to the Soviet communist dictatorship. His regime had an extremely personal character. He treated the country as his and his family's private domain. In this sense, Trujillo can be compared to other Latin American (or, more precisely, Central American dictators) such as "Papa Doc" Duvalier of Haiti and Somoza of Nicaragua. All of them used their power not only to totally dominate the political and social life of their countries, but also to gain the property and most valuable assets of the national economies.

The pillars of the dictatorship were rather typical: bureaucracy, army and secret police. After eliminating all independent political movements in the first two decades of his reign, Trujillo established a one-party system. He maintained a pretence of democracy and its most fundamental institution - elections. It is clear, however, 
that no electoral voting during the thirty years of his control was free. With the passing of time, Trujillo tried to strengthen his image as a democratic leader, resigning from the position of president. Trujillo's office was first occupied by his brother Hector. Next, he set up Joaquin Balaguer in the position of head of state. Balaguer was clearly a puppet president, but the nomination of a person from outside of the ruling family, with an intellectual appearance, served the regime's image improvement (Łepkowski 1983: 190, 356; Rabe 1999: 38). Trujillo was under growing pressure from global public opinion. The superficial change was aimed at convincing observers of the growing openness of the system.

One of the most characteristic features of the regime was the cult of personality. Trujillo wanted to be seen, and probably envisioned himself, as a Benefactor, a leader who secured prosperity and order in his country. In fact, the indisputable economic growth of the Dominican Republic under his rule made it easier to believe in the image of him as a benefactor. The growth and professionalization of the military forces made social mobility much easier; many poor people from rural areas were able to change their social status by means of a military career (Turtis 2005: 1568). This was another factor which contributed to the popular support for Trujillo. Society was instantly indoctrinated by the ideology which expressed admiration for el Jefe ("the Chief," as Trujillo was called), to whom progress and security were attributed. One of the most spectacular examples of this cult was the renaming of the capital city, Santo Domingo, to Ciudad Trujillo (Trujillo City) (Dobrzycki 165-166; Derby 301-302). ${ }^{2}$

The Trujillo regime definitely had a racist character. His ambition was to make Dominican society more "white." Thus, Trujillo supported immigration from Europe. Immigration from Nordic countries was especially encouraged (Eepkowski 1983: 55). This concept also influenced his policy in the army, which should - according to his views - also become "white."

A system of repression was one of the fundamental features of the regime. The indoctrinated society was permanently invigilated and repressed by the political police. Its most repressive and powerful branch, Servicio de Inteligencia Militar, was led by Abbes Garcia during the fall of the regime. Repressive tactics, including political murders and torture, were the typical methods of eliminating opposition and maintaining a "culture of fear" in society. The intention of the authorities was to create the popular conviction that no one was safe in the Republic, and that punishment would await anyone who questioned the power of el Jefe. But the repressions never became massive; the only example of a large-scale mass murder committed by the Trujillo regime was the massacre of Haitians who lived in the Dominican Republic in 1937. The repressions throughout the dictatorship were aimed rather at limited groups and individuals (Derby 303; Roorda 301-319).

For most of the 1950s, the United States accepted the Dominican dictatorship, though without enthusiasm. The fact that Trujillo violated human rights and committed crimes never persuaded the U.S. administration either to publicly condemn the dictator, or to make an informal attempt to influence Trujillo. Such an attitude negatively influenced the image of the United States among Latin Americans (U.S.

2 Another example from the official Trujillo cult was the change in word order in the formula "Dios y Trujillo" to "Trujillo y Dios." 
Congress. Senate 191). The United States tolerated the atrocities of the Trujillo regime, criticizing at the same time other governments for undemocratic practices. It is a kind of paradox that Juan Domingo Peron, the populist leader of Argentina, received the label of fascist in the public speeches of U.S. officials and was fought by the United States after the Second World War, when his government never violated human rights to such an extent as Trujillo. But Peron questioned U.S. policy; in the eyes of the U.S., his neutral stance weakened the unified frontier of American republics (Łepkowski 1983: 291-292).

The United States began to change its attitude toward the Trujillo regime because of the Cuban revolution and growing anxiety caused by Trujillo's foreign policy. After 1956, a crisis in many old dictatorships was observed. By the end of the decade, many countries had adopted forms of electoral systems and allowed representation, at least to some extent. Trujillo observed with anxiety the fall of many Latin American dictators in the 1950s. By the year 1959, the dictatorial regimes in Honduras, Columbia, Venezuela and Cuba had fallen (Taffet 125). The Dominican Republic was one of the countries which did not democratize its political system, together with Cuba, Haiti, Nicaragua, and Guatemala (Eakin 267).

One of the events that tarnished Trujillo's image in the United States was the Galindez case. Jesus Galindez, an émigré from the Dominican Republic, lectured at Columbia University. He was an avid critic of Trujillo, whose rule he had observed when he lived in the Dominican Republic. ${ }^{3}$ After being involved in underground activity against Trujillo, his American friends helped him to move to the United States, probably saving his life. Galindez wrote a dissertation on Trujillo's dictatorship and submitted it for a Ph.D. degree at Columbia University. He also published many very critical texts on Trujillo. He disappeared on 12 March 1956, after classes with his students ("The Critic Vanishes" 43). Galindez was kidnapped by Trujillo's secret police and brought to the Dominican Republic. Trujillo's agents used American aviator Charles Murphy, unaware of his role, to carry out the operation (he piloted the plane with Galindez aboard to the Dominican Republic). Murphy soon disappeared. The next victim was Octavio de la Maza, aviator and Murphy's friend, who reportedly took responsibility for Murphy's death and committed suicide. Nevertheless, the real author of this "procession of deaths" was unable to hide; the responsibility of Trujillo for the kidnapping and murdering of these people was unquestionable for U.S. public opinion. Senators Charles Porter and Wayne Morse started questioning publicly the U.S.'s alliance with the ruthless dictator (Rabe 1988 154). Moreover, this act of violence on American soil caused serious protests amongst the American public. Without enthusiasm, the State Department had to investigate the murders (Rabe 1996: 59).

The reactions to the disappearance of Galindez irritated Trujillo, who seemed to no longer care about Washington's wishes. In 1959, when the Eisenhower administration suspended arms supplies to Cuba, Trujillo ignored the policy of the U.S.A. and started to deliver arms to Batista (Rabe 1988: 155). The dictator was afraid that the victory of the Cuban revolutionary would put his own position in danger. This presumption was absolutely right, because when Castro took over power in Cuba,

Galindez, a Basque, came to the Dominican Republic from Spain, which he left after the republicans' defeat. Trujillo opened his country up to republican émigrés from Spain, which very positively contributed to his publicity in the Western World. 
he began a campaign against Trujillo. The external threat for the Dominican dictatorship appeared more serious at that time than any internal plot, which seemed hardly possible (U.S. Department of State 1991: 367).

U.S. policymakers judged that the Trujillo regime was going through a deepening crisis. They attributed the problems of the dictatorship to the economic troubles of the republic (decreasing global prices of Dominican products and budget shortages caused by excessive military expenditures). The deteriorating economic situation stimulated the growing opposition against the Benefactor, which came from the middle class (which had been one of the pillars of the system up until that point). U.S. agencies considered Cuba and Venezuela to be foreign sponsors of subversive activity against Trujillo and a real threat to his power. What troubled Washington was the revolutionary character of the movements inspired and supported by Havana and Caracas (U.S. Department of State 1991: 422-423).

In fact, like Americans, Trujillo considered Cuba and Venezuela a major threat to his power. The president of Venezuela, Romulo Betancourt, was one of the most notable reformist leaders in Latin America. A former leftist radical, Betancourt personified hope for the democratization of Latin American countries, and became one of the most ardent critics of Trujillo (Rabe 1996: 60).

The Dominican dictator chose the worst way of dealing with the new opponent in the Western Hemisphere, but probably his favourite way: he decided to murder the Venezuelan president. On 24 June 1960, Trujillo's agents detonated a bomb near the passing car of the Venezuelan president. Betancourt survived, however, with severe burns (Rabe 1996: 67).

President Eisenhower began to consider Trujillo as a threat equal to Castro. The administration was afraid that the continuation of the regime would create a revolutionary situation in the Dominican Republic. In other words, Trujillo was dangerous for the United States because his fall through a revolution could produce another Castro-type regime. Thus, the USA supported the idea of ousting Trujillo from power. The failure of diplomatic attempts confirmed the United States in the conviction that the plans of overthrowing Trujillo by force should be supported (U.S. Congress. Senate 191-192).

One of the main problems of this concept was a total lack of organized opposition with a leader. There were people who planned to assassinate Trujillo, but there was no plan concerning what should be done after the death of el Jefe. The United States was ready to support a "suitable successor regime" and give the new leader "U.S. political, military and - if necessary - military support" (Memo qtd in U.S. Congress. Senate 192). The State Department and the CIA also approved the supply of a small number of rifles to the Dominican underground opposition. It may seem surprising that so few weapons could be helpful for plotters, but the Dominican Republic was free of privately owned weapons. ${ }^{4}$ The most important members of the Trujillo regime were the targets against whom the "sterile" (i.e. untraceable) rifles were to be used (U.S. Congress. Senate 193-194).

The U.S. ambassador to the Dominican Republic, John Farland, established contact with "dissidents," as the members of opposition groups were called in U.S.

4 The country was cleared of armaments during the U.S. occupation. Trujillo continued this policy. 
documents and diplomatic cables. The Deputy Chief of the Mission, Henry Dearborn, became the person responsible for contact with them and a link with the CIA. Dearborn's sensitive role got "unofficial" approval from the Assistant Secretary of State for Inter-American Affairs, Roy Rubbotom (U.S. Congress. Senate 192).

Obviously, the situation in the Dominican Republic was one of the first challenges that the Kennedy administration had to face. President John F. Kennedy wanted to redefine the policy toward Latin America. It was part of the broader plan of a new foreign policy, which - according to Kennedy's intentions - was to return to the United States its position of superiority in international relations. Kennedy consciously made Cuba the leitmotiv of his presidential campaign in 1960. He wanted to avoid being labelled as a politician who was "too soft on Communism," a political curse which had been haunting the Democratic Party since the Second World War. Kennedy wanted to be seen as a strong leader who would be able to contain Castro's Communism in the Western hemisphere. Thus, he harshly criticized the reported passivity of the Eisenhower administration towards the Cuban revolution (Dallek 290; Smith 102).

At the same time, Kennedy was aware that the revolutionary movements in Latin America were not a product of Soviet propaganda. He had tried to emphasize the problems of underdevelopment and deficit of democracy in the Third World years before he became the president (Rabe 13; Taffet 24-26). The Cuban revolution was proof that the U.S.'s indifference towards Latin American economic and social tensions, and American support for repressive regimes, could have a disastrous result for the Western Hemisphere's political stability (Kennedy 131-133).

In this situation, containing the revolution in Latin America must have been one of the priorities for the new, Democratic administration. Kennedy described Latin America as "the most dangerous area in the world," and these words expressed his profound concern that "another Cuba" might appear there. From this point of view, Central America and the Caribbean formed a particularly important region for U.S. national security (Rabe 1999: 19; U.S. Department of State 1997: 172). The Kennedy administration assumed correctly that significant economic aid for Latin American nations could be a very effective tool of foreign policy. This was the genesis of the Alliance for Progress, the greatest economic aid program which the United States has offered Latin America in the history of inter-American relations (Fatalski 36-44; Taffet 23-26). The U.S. administration assumed that economic progress and social reforms supported by U.S. financial and conceptual assistance would diminish the attractiveness of Marxism in the eyes of Latin Americans. Kennedy demanded that Latin American political elites implement the necessary reforms to improve living conditions and reduce social tensions (Dallek 340-342, 435-436).

An equally important aim of the administration was the promotion of democracy in Latin American countries. The Kennedy team believed that building representative systems based on free elections was a sine qua non condition of success of their project for Latin America. This idea was based on the idealistic concept of a "middle class revolution," a process which was reportedly taking place in Latin America at that time. ${ }^{5}$ The middle class was to be an inspiring factor and cornerstone of democracy (Taffet 11, 21-22).

5 Among President Kennedy's advisers were distinguished intellectuals such as Walt Rostow and Arthur Schlesinger Jr. Rostow was an author of modernization theory. He 
In this context, the Dominican Republic was one of the most important challenges for the Kennedy administration. Moreover, taking into consideration the worsening situation in this country, which was interpreted in Washington as increasing the threat of revolution, this case was also urgent. The Kennedy administration continued the policy worked out by his predecessor, supporting the idea of the Dominican opposition ousting Trujillo with U.S. assistance. The president considered further economic sanctions against Trujillo through eliminating the sugar quota (the purchase of sugar by the U.S.A.). However, he was afraid of the fall of Trujillo and a Communist revolution as a consequence of sanctions (U.S. Department of State 1997: 616). American policymakers did not consider the fall of Trujillo as "imminent." They were aware that opposition was getting stronger. This opposition, composed of "business, student and professional people," was "predominantly anti-Communist." But they were afraid of the émigrés who were plotting against Trujillo in Cuba and Venezuela, and even in the United States. These groups were believed to be infiltrated by "pro-Castro or pro-Communist elements." Thus, the Kennedy administration preferred the success of the domestic opposition in the fight against Trujillo because it made the danger of a Communist takeover less possible. U.S. policymakers were aware that a decisive position toward Trujillo was necessary if the United States wanted to successfully carry out its plans in Latin America. It was important for U.S. credibility, especially when the administration expected other Latin American governments to join the anti-Castro alliance. "Our ability to marshal Latin American support for the Castro dictatorship would be impaired [without action against Trujillo]," wrote Secretary of State Dean Rusk. "Venezuela had made it clear that action against Trujillo is a condition precedent to Venezuelan support of collective action against Castro" (U.S. Department of State 1997: 617).

One of the main problems of U.S. policymakers was the lack of a clear perspective concerning what would be the possible development of the situation in the Dominican Republic after the fall of Trujillo. Dearborn, who was the most involved U.S. official in Dominican affairs, expected "some bloodshed." He judged that "the longer Trujillo continues to dominate the D.R. the more susceptible the country is becoming to leftist extremists, and that, therefore, Trujillo's overthrow in the near future would be in the interest of the U.S." (U.S. Department of State 1997: 622-623).

Kennedy still tried to negotiate with Trujillo a peaceful transition of power. Distrustful of the Department of State, Kennedy sent to the Dominican Republic a former Foreign Service officer, Robert Murphy, with a kind of special mission Murphy was accompanied by Igor Cassini, an informal agent of Trujillo's interests in the United States. ${ }^{6}$ What is interesting, the State Department was not informed about the mission (Dearborn 39; Rabe 1997: 38). The conclusion of Murphy's report was critical toward U.S. policy; he encouraged a more friendly policy toward Trujillo as a better method of dealing with the dictator. But McGeorge Bundy, Kennedy's Special

explained his ideas in "Stages of Economic Growth." Schlesinger, a strong supporter of reform programs in Latin America, believed in the ability of the USA to induce progress and democratization in Latin America (Report to the President on the Latin American Mission February 12-March 3, 1961, FRUS 1961-1963, Vol. XII, 11).

6 Cassini's brother, Oleg, designed dresses for Jacqueline Kennedy (Rabe 1997: 38). 
Assistant for National Security Affairs, was very sceptical. He warned Kennedy that "the whole concept of the Alliance for Progress would be gravely shadowed in the eyes of Latin Americans if we were to move to anything like a policy of friendly guidance toward Trujillo" (U.S. Department of State 1997: 625).

Soon afterwards, the United States defined its political aims in its policy toward the Dominican Republic. "The paramount interest of the U.S. is to prevent Castro-Communist or other unfriendly elements from taking control and to insure that Trujillo is succeeded by a friendly, democratic government." The administration assumed that in the case of constituting a friendly government after ousting Trujillo, the new authorities would receive U.S. assistance. But if Trujillo were able to continue his reign, the U.S.A. would not change its policy and would still support "dissidents" (U.S. Department of State 1997: 629-633).

Fifteen days later, on 30 May 1961, on the day of "the feast of the Goat," Trujillo was assassinated by Dominican conspirators. The action "closely paralleled" the plans that were known by the CIA and the Department of State. American weapons had been passed on earlier to the members of the "action group." The involvement of the United States in the affair seemed clear, since Kennedy's press secretary, Pierre Salinger, made a public announcement about the death of Trujillo several hours before the official announcement by the Dominican Republic's government. The president was in Paris on that day (U.S. Congress. Senate 213-214). In fact, Kennedy and his people were somewhat surprised by the timing of the assassination. The president had given orders to act with restraint. The death of the dictator was the beginning of the end of the regime. But the end did not come immediately; initially the regime appeared stronger than its architect. The main reason why the regime lasted without Trujillo in command was probably the attitude of the army. No one among the military commanders questioned the legitimacy of Trujillo's son, Rafael Leonidas Trujillo Jr., called Ramfis, to take power. The only person who was involved in the conspiracy against the dictator was General Jose Roman Fernandez, secretary of the armed forces. However, he failed the hopes of the plotters (Turtis 2003: 260-261). Soon he paid the highest price for his passivity, and was executed by secret police. Ramfis immediately returned to the Dominican Republic from Spain, where he had been leading the life of a playboy and millionaire. Unstable and cruel, he had none of his father's talents (Ornes 215-218). After his arrival, he took control over the military and started to haunt the plotters who had killed the dictator. At the same time, the position of the President of the Republic became stronger. Balaguer wisely manoeuvred between various segments of the Trujillo system and promised that free elections would be organized in the Dominican Republic. The U.S. administration was concerned about the possibility of Communist forces taking power. Americans assured Balaguer that the United States was ready to "give prompt military support" in the case of a Communist invasion from abroad. At the same time, the United States encouraged Balaguer "to adopt anticommunist law." The United States began to rely considerably on Balaguer, who seemed to be a guarantee of an anti-Communist direction of government and - at the same time - the transition to democracy. Balaguer was assured of U.S. support for his policy and encouraged to "clean up the security police, to make electoral reforms, and to allow legitimate, non-Communist opposition groups to operate openly..." (U.S. Department of State 1997: 647-653). 
The U.S. policy toward the "Dominican case" in 1961 was reflected in the often-quoted words of President Kennedy: "There are three possibilities of descending order of preference: a decent democratic regime, a continuation of the Trujillo regime, or a Castro regime. We ought to aim at the first, but we really can't renounce the second until we are sure we can avoid the third" (Schlesinger 769).

The United States was initially inclined to wait till May 1962, when the free elections promised by Balaguer were to be organized. Till that date, the Kennedy administration wanted to deal somehow with Trujillo. But the developments in the Dominican Republic did not allow Kennedy and his advisers to wait. The president, afraid of the possible consequences of the continuation of the Trujillo regime, had a special envoy sent to the Dominican Republic to convince the Trujillo family to leave the island. When the mission failed, the United States threatened the Trujillos with intervention if they tried to restore their dictatorship. This meant that the Kennedy administration demanded that Ramfi and his family leave the country. The will of President Kennedy, expressed by Dean Rusk, was correctly interpreted by the Trujillos. They left the Dominican Republic 20 November 1961 (Rabe 1999: 42-43).

The United States's policy toward the Trujillo regime is a good example of the evolution of the U.S.'s policy toward Latin America and the dilemmas of U.S. policymakers during the Cold War. Initially, the U.S.A. supported Trujillo as a close ally. This alliance became even more valuable in the face of the global confrontation with Communism and the Soviet Union. In the late 1950s, however, the United States started to consider the Dominican dictatorship as a growing threat to their interests. The Eisenhower administration was concerned that the continuation of the regime would cause Batista-like conditions in the Dominican Republic and would eventually lead to another revolution. For the Kennedy administration, Trujillo was the antithesis of their idealistic aims in Latin America. Thus, the United States decided to give their assistance to those who had decided to oust Trujillo from power. The death of the dictator began a long period of turmoil in the domestic affairs of this Caribbean country. The Kennedy administration was criticized by the American republics for its involvement in the Dominican Republic's internal affairs; it was accused of returning to a policy of intervention. But it is uncertain whether the Trujillo regime would have been terminated without Kennedy's pressure in October 1961. It was an unquestionable contribution by the United States and its president to the idea of democracy-promotion and defence of human rights.

\section{References}

“The Critic Vanishes.” Time 2 April 2 1956: 43.

Dallek, Robert. An Unfinished Life: John F. Kennedy 1917-1963. Boston: Little, Brown and Company, 2003.

Dearborn, Henry. Interview by Charles Stewart Kennedy. Foreign Affairs Oral History Collection, Association for Diplomatic Studies and Training, Arlington, VA. 8 July 2013. http:/ / www.adst.org/OH\%20TOCs/Dearborn, \%20Henry.toc.pdf.

Derby, Lauren. "In the Shadow of the State: the Politics of Denunciation and Panegyric during the Trujillo Regime in the Dominican Republic, 1940-1958." Hispanic Historical American Review 83:2, 2003: 295-344. 
Dobrzycki, Wiesław. Stosunki międzynarodowe w Ameryce Łacińskiej: historia i wspótczesność. Warszawa: Wydawnictwo Naukowe Scholar, 2000.

Eakin, Marshall C. Historia Ameryki Łacińskiej: Zderzenie kultur. Kraków: Wydawnictwo Uniwersytetu Jagiellońskiego, 2007.

Fatalski, Marcin. Widmo rewolucji: Polityka USA wobec Ameryki Południowej 1961-1968. Kraków: Wydawnictwo Uniwersytetu Jagiellońskiego, 2011.

Gildherus, Mark T. “The Monroe Doctrine: Meanings and Implications.” Presidential Studies Quarterly 36.1, 2006. http:/ / dx.doi.org/10.1111/j.1741-5705.2006.00282.x.

Gruszczak, Artur. Ameryka Środkowa. Warszawa: Trio, 2007.

Kennedy, John F. The Strategy of Peace. New York: Harper \& Bros., 1960.

Kissinger, Henry. Dyplomacja. Warszawa: Phillip Wilson, 2002.

Kłosowicz, Robert. U.S. Marines jako narzędzie polityki zagranicznej Stanów Zjednoczonych Ameryki. Kraków: Wydawnictwo Uniwersytetu Jagiellońskiego, 2008.

Łepkowski, Tadeusz (ed.). Dzieje Ameryki Łacińskiej od schyłku epoki kolonialnej do czasów wspótczesnych. Vol. 2. Warszawa: Książka i Wiedza, 1979.

Łepkowski, Tadeusz (ed.). Dzieje Ameryki Łacińskiej od schyłku epoki kolonialnej do czasów wspótczesnych. Vol. 3. Warszawa: Książka i Wiedza, 1983.

Ornes, German E. Trujillo: Little Caesar of the Caribbean. New York: Thomas Nelson and Sons, 1958.

Rabe, Stephen G. "The Caribbean Triangle: Betancourt, Castro and Trujillo and U.S. Foreign Policy, 1958-1963." Diplomatic History 20.1, 1996: 55-78.

Rabe, Stephen G. Eisenhower and Latin America: The Foreign Policy of Anticommunism. Chapel Hill: The University of North Carolina Press, 1988.

Rabe, Stephen G. The Most Dangerous Area in the World: John F. Kennedy Confronts Communist Revolution in Latin America. Chapel Hill: The University of North Carolina Press 1999.

Roorda, Paul Eric. "Genocide Next Door: The Goode Neighbor Policy, the Trujillo Regime and the Haitan Massacre of 1937." Diplomatic History 20.3, 1996: 301-319.

Schlesinger, Arthur M. A Thousand Days: John F. Kennedy in the White House. Boston: Houghton Mifflin, 1965.

Schoultz, Lars. Beneath the United States. A History of U.S. Policy Toward Latin America. Cambridge, Massachusetts, 2003.

Smith, Gaddis. The Last Years of the Monroe Doctrine, 1945-1993. New York: Hill and Wang, 1994.

Taffet, Jeffrey F. Foreign Aid as Foreign Policy. The Alliance for Progress in Latin America. New York: Routledge, 2007.

Turtis, Richard Lee. Foundations of Despotism: Peasants, the Trujillo Regime and Modernity in Dominican History. Stanford, California: Stanford University Press, 2003.

Turtis, Richard Lee. Rev. of The Militarization of Culture in the Dominican Republic, from the Captains General to General Trujillo Valentina Peguero. American Historical Review 110.5, 2005: 1567-1568.

U.S. Congress. Senate. Alleged Assassination Plots Involving Foreign Leaders. An Interim Report of the Select Committee to Study Governmental Operations with Respect to Intelligence Activities, United States Senate together with Additional, Supplemental and Separate Views, November 20, 1975. Washington: U.S. Government Printing Office, 1975.

U.S. Department of State. Foreign Relations of the United States, 1958-1960. Vol. 5. Washington: Government Printing Office, 1991. 
U.S. Department of State. Foreign Relations of the United States, 1961-1963. Vol. 12. Washington: Government Printing Office, 1997.

U.S. Senate, Nomination of John Foster Dulles, Secretary of State Designate: Hearing Before the Committee on Foreign Relations on the Nomination of John Foster Dulles, Secretary of State Designate, 15 January 1953, 83 ${ }^{\text {rd }}$ Congress, $1^{\text {st }}$ Session. Washington D.C.: United States Printing Office, 1953. 